\title{
Fanconi Anemia Core Complex-Associated Protein 24
}

National Cancer Institute

\section{Source}

National Cancer Institute. Fanconi Anemia Core Complex-Associated Protein 24. NCI

Thesaurus. Code C92480.

Fanconi anemia core complex-associated protein 24 (215 aa, $24 \mathrm{kDa}$ ) is encoded by the human FAAP24 gene. This protein plays a role in linking the Fanconi anemia DNA repair complex to damaged DNA. 